\title{
Sanitation Regulation in Indonesia: Obstacles and Challenges to the Achievement of SDGs Targets
}

\author{
Victor Imanuel W. Nalle ${ }^{1^{*}}$, Martika Dini Syaputri ${ }^{2}$ \\ ${ }^{1}$ Darma Cendika Catholic University, Indonesia \\ ${ }^{2}$ Darma Cendika Catholic University, Indonesia \\ *Corresponding author
}

\begin{abstract}
.
Data from the Ministry of Public Works and People's Housing of the Republic of Indonesia in 2017 showed that only 34 from 541 regencies/cities in Indonesia have regional regulations on sanitation. If there is no significant increase in the availability of regional regulations on sanitation management until 2019, the government in the 2019-2024 period needs to have a strategy to accelerate the establishment of regional regulations on sanitation in all regencies/cities. This research was conducted to identify regulatory and bureaucratic constraints that prevented the acceleration of the establishment of regional regulations on sanitation in supporting the achievement of $100 \%$ access to appropriate sanitation in the Sustainable Development Goals. The interim findings in this research indicated that one of the factors that hindered the acceleration of the establishment of regional regulations was the slow pace of the executive and legislative bodies in ratifying the Sanitation Laws and Regulations. In fact, the discussion of regional regulations on sanitation in several regions was generally obstructed because regional parliaments questioned whether there was a law or a juridical basis for the establishment of the regional regulations. On the other hand, the executive and legislative bodies also did not immediately make a new Law on Water Resources after the previous Law on Water Resources was canceled by the Constitutional Court. Another factor that impeded the acceleration of the establishment of regional regulations on sanitation in various regions was the absence of policies that were able to integrate national and regional legislation programs with development plans at the national and regional levels. The lack of integration of legislation and development plans was also influenced by weak coordination between the Ministry of Law and Human Rights, the National Development Planning Agency, and the Ministry of Home Affairs.
\end{abstract}

Keywords: sanitation; universal access; regional regulations; development planning; legislation program 


\section{Introduction}

The 1945 Constitution has expressly stated that one of the ideals of the Unitary State of the Republic of Indonesia is the realization of social justice for all Indonesian people. The vision of the realization of social justice is elaborated in the substance of the 1945 Constitution through the regulation of constitutional rights to ensure the achievement of social justice. Guarantees of citizens' constitutional rights include elementary aspects in human life, including economic, political, social, environmental, and cultural aspects. The constitutional rights related to the environment are guaranteed in Article 28H paragraph (1) of the 1945 Constitution, namely: "Every person has the right to live in physical and spiritual prosperity, to live and get a good and healthy environment, and to receive health services."

The right to obtain a good and healthy environment can be guaranteed through the role of the country in the macro and micro scope. The role of the country in the macro scope is implemented by establishing laws and regulations that protect the entire ecosystem of the environment. One of the roles of the country that has been carried out within this macro scope is forming Law No. 32 Year 2009 concerning Environmental Protection and Management. In addition to acting within the macro scope, the country plays a role in the micro scope, namely in the aspect of sanitation.

Based on Law No. 23 Year 2014 concerning Regional Government (Law on Regional Government), the field of sanitation (domestic and waste water) is a government affair that is divided between the central, provincial and regency/city governments, and is a mandatory business related to basic services which is the authority of the provincial and regency/city governments. However, there are still many provincial and regency/city governments that have problems in achieving access to appropriate sanitation. On the other hand, the 2015-2019 National Medium-Term Development Plan (RPJMN) mandates that Indonesia will achieve $100 \%$ universal access to safe sanitation in 2019. This means that until the end of the year, every Indonesian people living in urban and rural areas has access to appropriate sanitation. According to Chaplin in Owusu (2010), one of approaches in overcoming sanitation problems is the establishment of adequate regulations.

The regulatory approach can be seen in the direction of policies to expand and improve basic services in the field of sanitation in Book II of the 2015-2019 RPJMN Development Agenda. The policy direction is to encourage regional governments to develop legal instruments to support the implementation of Minimum Service Standards in the field of sanitation. One of the legal instruments is in the form of regional regulations regarding the management of domestic wastewater as a form of attribution of authority to regional government regulated in the Regional Government Law. The policy direction is in line with the opinion of Rosensweig et.al (2012), who stated that the existence of regulations at the regional level that regulate sanitation services plays a role in strengthening sanitation management capacity. The challenge of this target is the need to accelerate the establishment of regional regulations on sanitation management in all regencies/cities.

The plan to form regional regulations should ideally pay attention to development planning in the regional and national scale. The plan to establish regional regulations can be conducted through the Regional Legislation Program which is prepared by taking into account regional development planning documents and is synchronized with higher legislation. However, based 
on Rayusman et al. (2014) in Way Kanan Regency, planning for the establishment of Regional Regulations is often not related to the Regional Medium-Term Development Plan (RPJMD) at

all. The proposed Draft Regional Regulation is also not implemented based on in-depth study by the initiator's regional apparatus.

Different models are applied by the Surakarta City Government. Based on the research of Danusastro (2012), the Surakarta City Government, in the preparation of the Regional Legislation Program in Surakarta City, firstly makes a list of the draft regional regulations that will be proposed with reference to the aspirations of the people. The title of the draft regional regulation can be derived from the draft of the previous year's regional regulations which have not yet been discussed, or new title of the draft regional regulation can be derived based on the proposal of the City Development Planning Forum.

In addition, several regional governments emphasize a bottom up approach in the establishment of regional regulations. This approach emphasizes the participation and involvement of the community in the administration of democratic countries. The community is involved in the process of formulating public policies and public decision-making processes and the reasons for public decision making (Rumesten, 2012). This approach looks democratic, but on the other hand, it also really needs to pay attention to the synchronization of policies from the central to regional levels so that the achievement of development goals at the regional level is in line with development objectives at the national level.

The results of the research in Way Kanan Regency and Surakarta City show that the tendency to form regional regulations is carried out without integrated planning with development planning documents. This condition can result in the low availability of regional regulations that support national and regional strategic programs in an integrated manner. Therefore, it is necessary to establish regional regulations whose content material is synchronized with the law, development planning documents at the national or regional level, and community aspirations.

In the sanitation sector, the establishment of regional regulations not only needs to pay attention to universal access targets in the 2015-2019 RPJMN, but also synchronization with the law. However, Indonesia actually has a legal vacuum at the national level because there is no law on sanitation that can be a juridical basis for the establishment of regional regulations on sanitation in regencies or cities. Therefore, this paper will analyze the factors that influence the legal vacuum and the impact on the availability of regional regulations on sanitation in the regencies/cities. These factors include regulatory as well as bureaucracy aspects at the central and regional levels.

\section{Method}

The research approach used in this research was explanatory research. According to Waaldijk (2009), an explanatory approach is used to find factors that influence the establishment or the implementation of law. Qualitative descriptive analysis in this research was conducted on primary data obtained from in-depth interviews with informants. Secondary data was obtained 
through studies of previous research results and reports from state institutions related to achieving sanitation access in Indonesia.

\section{Discussion}

\subsection{Sanitation in Indonesia and the Achievement of SDGs Targets}

The awareness of the importance of the role of the country in the aspect of environmental sanitation has intensified since the establishment of the Millennium Development Goals (MDGs). On September 28, 2011, the UN Human Rights Council also formulated a new resolution relating to human rights to drinking water and appropriate sanitation (Human Rights Council Resolution A/HRC/RES/18/1). The UN Human Rights Council through the resolution called on UN member states to guarantee sufficient funding for the sustainability of water and sanitation services (Winkler, 2015).

The MDGs target in the field of sanitation was also continued by the Sustainable Development Goals (SDSs) and became the 6th Goal of the SDGs namely "Clean Water and Sanitation for All". One of the indicators for the 6th goal includes achieving adequate and appropriate sanitation and hygiene access for all and zero percent $(0 \%)$ of open defecation (Spijkers \& Honnibal, 2014).

The global target in the sanitation sector was then adopted in the 2015-2019 RPJMN. One of the directions for the 2015-2019 RPJMN policy was to support basic sanitation services by targeting $100 \%$ access to basic and appropriate sanitation in Indonesia in 2019. Based on data obtained by the National Development Planning Agency (Bappenas), the achievement on access to basic and appropriate sanitation in Indonesia in the end of 2016 reached $76.37 \%$. This achievement was slightly below the target of $77.40 \%$ (National Development Planning Agency, 2017). In 2017, Bappenas has actually recommended several policies that need to be taken to achieve the target of 100\% access to basic and appropriate sanitation in 2019.

One of the recommendations from Bappenas to reduce the gap in the target was to draft regulations to strengthen the legal basis for sanitation development budgeting both at the central and regional levels (National Development Planning Agency, 2017). The importance of the regulatory aspects has actually been identified in the 2015-2019 RPJMN document. Book III of the 2015-2019 RPJMN has recommended one direction for achieving the target of 100\% access to basic and appropriate sanitation is the availability or strengthening of the regulatory framework for sanitation development institutions in the region. Therefore, Indonesia ideally has complete sanitation regulations from the central to regional levels. The next section of this article will outline the urgency of establishing the Sanitation Law and Regulations in Indonesia.

\subsection{Why are the Sanitation Laws and Regulations needed?}

Sanitation is an integral part of human rights to water. Recognition of human rights to sanitation and water can be seen in the General Comment No. 15 of the International Covenant on Economic, Social and Cultural Rights (ICESCR) which has been ratified by Indonesia through Law No. 11 Year 2005. The General Comment stated that access to appropriate sanitation is not only a part of protecting human dignity, but also a means to protect the quality of drinking water. The right to sanitation is also a core obligation of the countries in the 
ICESCR. The Covenant obliged states to take steps to prevent and monitor water-related diseases, especially providing the right to appropriate sanitation (Ellis \& Feris, 2014).

Indonesia's constitutional guarantee of the right to appropriate sanitation can be linked to Article 28H paragraph (1) of the 1945 Constitution, namely: "Every person has the right to live in physical and spiritual prosperity, to live and get a good and healthy environment and to obtain health services." The linkage of Article $28 \mathrm{H}$ paragraph (1) can be related to interpreting the scope of the "environment" in the article. The interpretation of the scope of the "environment" refers to the ICESCR which explicitly alluded to the theme "environment" in Article 12 as part of "the right of everyone to enjoy the highest standards of physical and mental health that can be achieved." The right to a good and healthy environment under the ICESCR includes several aspects including:

a. the right to housing, especially related to the fulfillment of the principle of convenience of residence;

b. the right to food, especially in relation to the government's obligation to formulate environmental policies that can support the fulfillment of the right to food; $c$. the right to education;

d. the right to a healthy work environment;

e. the right of every human being to get guarantees of prevention, care and supervision of disease outbreaks;

f. the right to water which aim to realize a number of other rights, including the right to the environment.

Sanitation access fullfillment guaratntee, if associated with the constitutional framework and ICESCR, is part of the constitutional rights of citizens to be free from epidemics and rights to water. The constitutional framework for fulfilling these guarantees can be achieved if the country provides substantive legal protection (Bedner, 2010) based on specific laws.

In order to realize substantive legal protection in fulfilling these rights, Sanitation Laws and Regulations are needed which regulates not only aspects of domestic waste but also drainage. The Draft Sanitation Laws and Regulations was not included in the National Legislation Program as one of the Draft Laws that will be discussed in the 2015-2019 period. The government at the end of 2016 then proposed the Draft to parliament to be an addition to the National Legislation Program. The draft was added to become part of the 2015-2019 National Legislation Program. However, the Draft Sanitation Laws and Regulations was never included in the list of priority discussions in 2018 and 2019.

The draft regulates domestic wastewater and drainage from the technical aspects of residential waste management, drainage systems, cooperation, to financing mechanisms. However, sanitation arrangements in a special law were also criticized because there were other laws that also specifically regulated water resources. Even though sanitation, drainage and water resources are a system that cannot be separated (Obani \& Gupta, 2015). Therefore, there should be integration of public policy, one of which is legislation, to provide a comprehensive normative framework for fulfilling the right to water and sanitation (Meier, et.al, 2013).

Indonesia has already ratified the Law on Water Resources in 2004. However, the Law on Water Resources was later canceled by the Constitutional Court because the substance was directed at the privatization of water which contradicted the spirit of the constitution so that the 
country controlled natural resources (Kamala, 2015). The House of Representatives of the Republic of Indonesia then drafted the Draft Law on Water Resources to replace the law which was canceled by the Constitutional Court. However, the Draft Law on Water Resources, which was later included in the legislative priority list in 2018 and 2019, also received the same criticism as the Draft Sanitation Laws and Regulations. The criticism was aimed at the Draft Law on Water Resources that did not integrate the sanitation and drainage sector as an integral part of the right to water. Water and sanitation are two inseparable sectors because the fulfillment of the right to sanitation cannot be implemented if access to water is not guaranteed by the country (Chandranegara, 2016).

This condition shows the weak coordination between the government and parliament in the legislation system in Indonesia to produce laws that are relevant to the targets in the mediumterm development plan. The government through the Ministry of Public Works and People's Housing drafted the Sanitation Laws and Regulations, while the parliament actually drafted the Draft Law on Water Resources and the formulation of the second substance of the draft law was carried out separately without synchronization. The two draft laws seem difficult to pass until the end of the government period in 2019 because parliamentarians are preoccupied with the general election agenda. Therefore, the legal vacuum at the level of the law in the sanitation sector is likely to continue until 2019. On the other hand, the government in the next period (2019-2024) certainly requires the availability of adequate regulations to resume the universal access target in sanitation sector. The legal vacuum in particular will have an impact on the absence of a strong legal basis for the regions (regencies/cities) to develop regional regulations in the sanitation sector.

\subsection{Domestic Waste Regulation from the Perspective of Regional Autonomy in Indonesia}

The impact of the absence of legislation in the sanitation sector on the achievement of sanitation in the regions is influenced by the mechanism of the distribution of authority between the central government and regional governments in Indonesia. Indonesia has regulated the division of authority between the central and the regional government quite tightly. The division of authority can be the basis for the regions to regulate it specifically with regional regulations. Based on the Law on Regional Government, the field of domestic waste is a government affair that is divided between the Central Government and the Regional Government, and is a mandatory business related to basic services that are under the authority of the Regional Government. Management and development of domestic waste in the regencies/cities scope is a mandatory affair of the regency/city government.

When regional governments want to draw up regional regulations on domestic waste, then regional governments need to pay attention to the boundaries of the scope that can be regulated in the regional regulations. The limitations on the scope refer to Law No. 12 Year 2011 (Law on the Establishment of Legislation). Based on the Law on the Establishment of Legislation, regional regulations are made to accommodate specific regional needs and/or as a further elaboration of higher legislation. Legislation with a higher position can be in the form of laws, government regulations, or regulations made by the ministry. However, Indonesia has not had a law specifically regulating sanitation. 
The Ministry of Public Works and People's Housing, the ministry responsible for access to sanitation in Indonesia, tries to overcome the problem of the absence of the sanitation laws and regulations. As explained in the previous section, the Sanitation Laws and Regulations were drafted by the Ministry but have never been discussed until the beginning of 2019. In

2017, the Minister of Public Works and People's Housing took the initiative to ratify the Minister of Public Works and Housing Regulation No. 4 Year 2017 concerning Domestic Waste Management System Implementation (Ministerial Regulation on Domestic Waste Management). Because this regulation was made by a ministry that was technically responsible, the substance of this Ministerial Regulation was also technical in nature and did not regulate in detail the aspects of institutional domestic waste management or financing mechanisms that could be taken by the regional governments.

The Ministry of Public Works and People's Housing tried to pursue the target of availability of domestic waste regulation in the regions by using the Ministerial Regulation as a guideline. The Ministry of Public Works and People's Housing has implemented an assistance program for regional governments in drafting regional regulations on domestic waste since 2016. Only 14 regions have succeeded in enacting regulations on domestic waste areas from 40 regions that have received assistance from the Ministry. ${ }^{1}$ In addition, there were 38 regions that had regional regulations without assistance. This amount was very small compared to 543 regencies/cities in Indonesia.

The lack of a number of regional regulations on sanitation that have been ratified, even though they have received assistance from the central government occured due to several constraints related to regulation and bureaucracy. These constraints are general in nature so that if they can be overcome they can have an impact in responding to the needs of central and regional regulations in other sectors. These obstacles include:

a. The classic problem in the regulatory system in Indonesia is the lack of integrated development planning systems at the central and regional levels with legislative planning (National Development Planning Agency, 2013). The national legislation program and the national medium-term development plan were made separately so that the Draft Sanitation Laws and Regulations was never considered part of the instruments needed to achieve the sanitation sector's target in the development plan. This problem cannot be separated from the paradigm of bureaucracy in Indonesia in looking at the development planning process. Various studies have found that most policymakers in Indonesia treat the development planning and budgeting stages as administrative and compliance procedures, not as a process to discuss substantive policy issues and consider whether the proposed solutions will actually have an impact (Blomkamp et al., 2017). Similar conditions can also be found in the area. The regional legislation program is also separate from the regional mid-term development plan. In the end, there is no synchronization of the priority scale of legislation with development priority which can be seen in the ambitious but never realized quantity target of legislation (Risnain, 2015).

\footnotetext{
${ }^{1}$ These areas include Siak Regency, Prabumulih City, Bintan Regency, Bangka Regency, East Belitung Regency, Temanggung Regency, Gunung Kidul Regency, Central Lombok Regency, Bolaang Mongondow Selatan Regency, Sarolangun Regency, Bangka Barat Regency, Lumajang Regency, Tulungagung Regency, Sorong Regency.
} 
b. The absence of coordination between the National Development Planning Agency, the Ministry of Law and Human Rights, the Ministry of Home Affairs and the regional government in integrating the stages of development planning with the planning of the preparation of national legislation and regional legislation programs. These regional laws and regulations, at present, seem to be legal products that are controlled by two different ministries. The laws are in the control of the Ministry of Law and Human Rights, while the regional regulations are in the control of the Ministry of Home Affairs.

c. There is no monitoring and evaluation mechanism for development planning and regulatory planning at the central and regional levels. The central monitoring and evaluation mechanism for the regions has been weak since the Constitutional Court in 2017 canceled the article in the Regional Government Law which authorized the Ministry of Home Affairs to overturn regional regulations.

d. Assistance carried out by the Ministry of Public Works and People's Housing since 2016 has produced several draft regional regulations in several regencies/cities. But some of them have not been approved by the regional parliament to be promulgated. It seems that members of the regional parliament do not yet have an agreement with the regent/mayor about the urgency of the existence of regional regulations on sanitation. Research conducted by Sholikin and Butt (2013) shows that legislators in the regions are more interested in drafting regional regulations relating to internal issues, including regional finance, regional taxes, and government institutions.

e. Assistance carried out by the Ministry of Public Works and People's Housing also has its own problems. Not all experts on academic drafting and draft regional regulations that work for the Ministry have adequate experience in legal drafter. The Ministry has drafted a draft regional regulation model to assist experts. However, most of the experts are too guided by the model so that they do not articulate localistic needs and ideas to be included in the draft regional regulations. On the other hand, not many civil apparatus in the regions have the capability to articulate technical and theoretical ideas into the draft regional regulations (Sherlock \& Djani, 2015). This condition has an effect on the cessation of the submission of draft regional regulations to regional parliaments to be discussed and ratified.

f. Other constraints that are localistic are changes in the leaders/heads of agencies in the regions or changes in the authorities in managing the sanitation sector. These changes become an obstacle when the draft regional regulations have actually been prepared and are ready to be submitted to the regional parliament. The new leaders of the agencies in the area consider not having the responsibility to continue the legislation agenda. This situation is a problem for the Ministry if the draft regional regulation is compiled from Ministry-financed assistance using the central government budget. The Ministry cannot intervene because the regional autonomy system in Indonesia places the position of regional agencies not as subordinate organizations of the Ministry.

These obstacles are interrelated and the problems that arise from these obstacles cannot be solved only from the initiative of sectoral ministries, namely the Ministry of Public Works and People's Housing. The problem of the legislative agenda at the central and regional levels with 


\section{SOCIAL SCIENCES IN THE 21ST CENTURY}

development plans at the central and regional levels can only be solved by legislation policies that are integrated with development planning policies.

\section{Conclusion}

To date, Indonesia has yet to have a policy that integrates legislation program and development plans. The legislation program and development plans for a period of 5 years are established by the government and parliament separately without synchronization. For the sanitation sector, the absence of such a policy makes it difficult for the government to achieve the target of universal access due to unavailability of supporting regulations at the regional level. One of the obstacles to synchronization is the lack of integration of the work plans of the three institutions, namely the National Development Planning Agency, the Ministry of Law and Human Rights, and the Ministry of Home Affairs.

The Ministry of Public Works and People's Housing also needs to make policy changes in assisting the establishment of draft regional regulations on sanitation in various regions. Weaknesses in the aspect of the limited capacity of experts working for the Ministry need to be evaluated so that the substance of the draft regional regulations resulting from assistance in the following year can better articulate technical and theoretical ideas at the regional level.

\section{Acknowledgment}

This article is one of the outputs of the research funded by the Ministry of Research and Higher Education of The Republic of Indonesia in 2019. The research will be carried out for 2 years. 


\section{References}

[1] Owusu, G. (2010). Social Effects of Poor Sanitation and Waste Management on Poor Urban Communities: a Neighborhood- Specific Study of Sabon Zongo, Accra. Journal of Urbanism, vol. 3, pp. 145-160.

[2] Rosensweig, F., Perez, E. \& Robinson, A. (2012). Policy and Sector Reform to Accelerate Access to Improved Rural Sanitation. Washington DC: World Bank.

[3] Rayusman, I.Z, Anwar, K. \& Tisnanta. (2014). Hubungan Program Legislasi Daerah dengan Perencanaan Pembangunan Daerah Kabupaten Way Kanan. Jurnal Kebijakan dan Pembangunan, vol. 1, pp. 29-53.

[4] Danusastro, S. (2012). Penyusunan Program Legislasi Daerah yang Partisipatif. Jurnal Konstitusi, vol. 9, pp. 643-660.

[5] Rumesten R.S, I. 2012. Model Ideal Partisipasi Masyarakat dalam Pembentukan Peraturan Daerah. Jurnal Dinamika Hukum, vol. 12, pp. 135-148.

[6] Waaldijk. K. (2009). "The Character of Scholarly Legal Research: Paradigms, Problems, Questions, Hypotheses, Sources, Methods". Universiteit Leiden, 6th Draft, August 302009.

[7] Winkler, I. T. (2015). The human right to sanitation. University of Pennsylvania Journal of International Law, vol. 37, pp. 1331-1406.

[8] Spijkers, O., \& Honniball, A. (2014). MDGs and SDGs: Lessons Learnt from global public participation in the drafting of the UN development goals. Vereinte Nationen: German Review on the United Nations, vol. 62, pp. 251-256.

[9] Badan Perencanaan Pembangunan Nasional. (2017). Evaluasi Paruh Waktu Rencana Pembangunan Jangka Menengah Nasional 2015-2019. Jakarta: Kementerian Perencanaan Pembangunan Nasional/Badan Perencanaan Pembangunan Nasional.

[10] Ellis, K., \& Feris, L. (2014). The right to sanitation: time to delink from the right to water. Human Rights Quarterly, vol. 36, pp. 607-629.

[11] Bedner, A. W. (2010). An Elementary Approach to the Rule of Law. Hague Journal on the Rule of Law, vol. 2, pp. 48-74. 


\section{SOCIAL SCIENCES IN THE 21ST CENTURY}

[12] Obani, P., \& Gupta, J. (2015). The evolution of the right to water and sanitation: differentiating the implications. Review of European, Comparative \& International Environmental Law, vol. 24, pp. 27-39.

[13] Meier, B. M., Kayser, G. L., Amjad, U. Q., \& Bartram, J. (2013). Implementing an evolving human right through water and sanitation policy. Water Policy, vol. 15, pp. 116133.

[14] Kamala, I. (2015). Harapan Baru Atas Pengelolaan Sumber Daya Air terkait Putusan MK Nomor 85/PUU-XI/2013. Jurnal Konstitusi, 12(3), pp. 422-446.

[15] Chandranegara, I. S. (2016). Purifikasi Konstitusional Sumber Daya Air Indonesia. Jurnal Rechts Vinding: Media Pembinaan Hukum Nasional, vol. 5, pp. 359-379.

[16] Badan Perencanaan Pembangunan Nasional. (2013). Background Study: Pengintegrasian Kerangka Regulasi dalam RPJMN 2015-2019. Jakarta: Kementerian Perencanaan Pembangunan Nasional/Badan Perencanaan Pembangunan Nasional.

[17] Blomkamp, E., Sholikin, M. N., Nursyamsi, F., Lewis, J. M., \& Toumbourou, T. (2017). Understanding Policymaking in Indonesia: In Search of a Policy Cycle. Jakarta: PSHK.

[18] Risnain, M. (2015). Konsep Peningkatan Kuantitas dan Kualitas Program Legislasi Nasional: Rekomendasi Konseptual dan Kebijakan pada Prolegnas 2015-2019. Jurnal Rechts Vinding: Media Pembinaan Hukum Nasional, vol. 4, pp. 399-411.

[19] Sholikin, M. N., \& Butt, S. (2013). Pembuatan Peraturan di Parlemen Daerah (DPRD). Canberra: Crawford School of Economics and Government.

[20] Sherlock, S, \& Djani, L. (2015). Update on Constraints in the Enabling Environment to the Provision of Knowledge in Executive and Legislative Government: Diagnostic Study. Jakarta: Knowledge Sector Initiative. 